\title{
Pim kinases in hematological malignancies: where are we now and where are we going?
}

\author{
Patrizia Mondello ${ }^{1,2^{*}}$, Salvatore Cuzzocrea ${ }^{2}$ and Michael Mian 3,4
}

\begin{abstract}
The proviral insertion in murine (PIM) lymphoma proteins are a serine/threonine kinase family composed of three isoformes: Pim-1, Pim-2 and Pim-3. They play a critical role in the control of cell proliferation, survival, homing and migration. Recently, overexpression of Pim kinases has been reported in human tumors, mainly in hematologic malignancies. In vitro and in vivo studies have confirmed their oncogenic potential. Indeed, PIM kinases have shown to be involved in tumorgenesis, to enhance tumor growth and to induce chemo-resistance, which is why they have become an attractive therapeutic target for cancer therapy. Novel molecules inhibiting Pim kinases have been evaluated in preclinical studies, demonstrating to be effective and with a favorable toxicity profile. Given the promising results, some of these compounds are currently under investigation in clinical trials. Herein, we provide an overview of the biological activity of PIM-kinases, their role in hematologic malignancies and future therapeutic opportunities.
\end{abstract}

Keywords: Pim kinases, Target therapy, Hematologic malignancies, Pim inhibitors

\section{Introduction}

The proviral insertion in murine (Pim) lymphoma family proteins, whose gene locus was discovered as a proviral integration site for Moloney murine leukemia virus infection, consists of three serine/threonine kinase isoforms: Pim-1, Pim-2 and Pim-3 [1]. These proto-oncogenic kinases are constitutively active and they are mainly regulated at the transcriptional and translational level $[2,3]$ by cytokines and growth factors involved in hematopoiesis, such as interleukin (IL)-2, IL-3 [4,5], IL-6, granulocytemacrophage colony-stimulating factor (GM-CSF) and granulocyte-colony stimulating factor (G-CSF) [6]. Furthermore, the stability and function of Pim kinases depend on their interaction with heat shock protein (Hsp) 90, a chaperone protein involved in folding and stabilizing different molecules [7]. Hsp90 showed not only to protect Pim-1 from ubiquitin-26S-proteasomal degradation, but also to mainten the proper conformation of Pim-1 [8].

Pim kinases play a critical role in the control of cell proliferation and survival. They are downstream effectors of important oncoproteins, such as Ableson (ABL) [9], Janus

\footnotetext{
* Correspondence: patriziamondello@hotmail.it

'Department of Human Pathology, University of Messina, Via Consolare

Valeria, 98125 Messina, Italy

${ }^{2}$ Department of Biological and Environmental Sciences, University of Messina, Messina, Italy

Full list of author information is available at the end of the article
}

Kinase 2 (JAK2) [10] and FMS-like tyrosine kinase 3 (FLT3) [11]. Although Pim kinases exert similar functions, they have different tissue distributions [12,13]. While Pim-1 and Pim-2 are predominantly expressed in hematopoietic cells $[12,14]$, Pim-3 expression is high in brain, kidney, and epithelia $[12,15]$. Due to their aberrant expression in human tumors [16-19], they could be important contributors in the pathogenesis of neoplasias including lymphomas, gastric, colorectal and prostate cancers [20].

The oncogenic potential of Pim kinases has been studied on transgenic mouse models. In the E $\mu$-pim 1 model only 5-10\% of mice developed T-cell lymphoma, suggesting that Pim-1 alone is not able to induce a massive proliferation [21]. Interestingly, infection of these transgenic mice with murine leukemia virus $(\mathrm{MuLV})$ promoting the integration of the provirus in the Pim-1 locus [22] enhanced dramatically the incidence of tumors and reduced the latency of T-cell lymphoma development [21]. The activation of either c-Myc or N-Myc was involved in every tumor, suggesting an oncogenic collaboration between Myc and Pim-1 genes in lymphomagenesis [21,23]. Co-expression of both $\mathrm{E} \mu-\mathrm{Pim} 1$ and $\mathrm{E} \mu-\mathrm{Myc}$ was incompatible with life, leading the transgenic mice to succumb to lymphomas in utero or around birth. Conversaly, E $\mu$-Myc;E $\mu$-Pim1 mice with low expression of c-Myc were viable and with low tumor incidence [24]. 
The oncogenic role of Pim-1 and its cooperation with c-Myc have also been studied in prostatic cancer. Pim-1 demonstrated to promote prostate tumorgenesis by enhancing the transcriptional activity of androgen receptors. Notably, Pim1-expressing cells presented an increased cMyc transcriptional activity as well. Treatment with the c-Myc inhibitor 10058-F4 reduced Pim-1 protein and suppressed the tumorigenicity of the prostate cancer cells [25]. In addition, Pim kinases have been demonstrated to cooperate with other oncogenes, such as bcl2 [26], bcl6 [27], runx2 [28], E2a-pbx1 [29], frat1 [30].

PIM knock-out studies have shown that mice deficient in all three Pim kinases are viable and fertile, supporting the tolerability of pan-Pim inhibition [12]. Mikkers et al. demonstrated that the lack of these kinases resulted in only a decrease of erythrocyte mean cell volume (MCV) [12]. However, a recent study has proved that the triple PIM knock-out affected multiple lineages of hematopoietic cells as well as the self-renewal of hematopoietic stem cells (HSCs) [31]. Based on these results a careful monitoring of potential hematological side effects is recommended with the Pim inhibitors treatment.

In this review we provide an overview of the biological background of Pim kinases, their role in hematologic malignancies and a summary of possible drugs targeting theses enzymes.

\section{The oncogenic potential of PIM kinases}

Pim kinases are critical components of distinct pathways that play an important role in cell proliferation and survival
[32-34] (Figure 1) and especially in apoptosis, cell cycle regulation, cell proliferation and cell migration.

\section{Apoptosis}

Pim kinases prevent cells from apoptosis by phosphorylating the proapoptotic Bcl-2-associated agonist of cell death (Bad). Phosphorylation of Bad on Serine (Ser) 112 and Ser136, respectively by Pim-1 and Pim-2, induces 14-3-3 binding, which results in loss of the binding with the anti-apoptotic protein $\mathrm{Bcl}-2$ and, consequently, in cell survival [35-37]. Similarly, phosphorylation of Bad on Ser155 by Pim-3 was found to prevent Bad from binding to the anti-apoptotic protein Bcl-xL [38]. In addition, the pro-survival activity of Pim kinases seems to depend also on direct phosphorylation of the apoptosis signaling kinase 1 (ASK1) [39], which decreases significantly ASK1 activity and inhibits ASK1-mediated phosphorylation of JNK and p38. Ultimately this phosphorylation event leads to blocking caspase-3 activation and decreasing apoptosis levels [39].

Pim kinases usually phosphorylate Mdm2 on Ser166 and 186, an E3 ubiquitin ligase which mediates ubiquitylation and proteasome-dependent degradation of p53 [40]. Notably, these residues are targets of other signaling pathways including Akt [41-46]. When Pim kinases are overexpressed, such as in tumors, they block the degradation of both p53 and Mdm2 in a Mdm2-independent manner, leading to an increase of p53. In addition, Pim-1 enhances p14ARF activity [40], a Mdm2 inhibitor well known to arrest the degradation of both p53 and Mdm2 itself $[47,48]$.

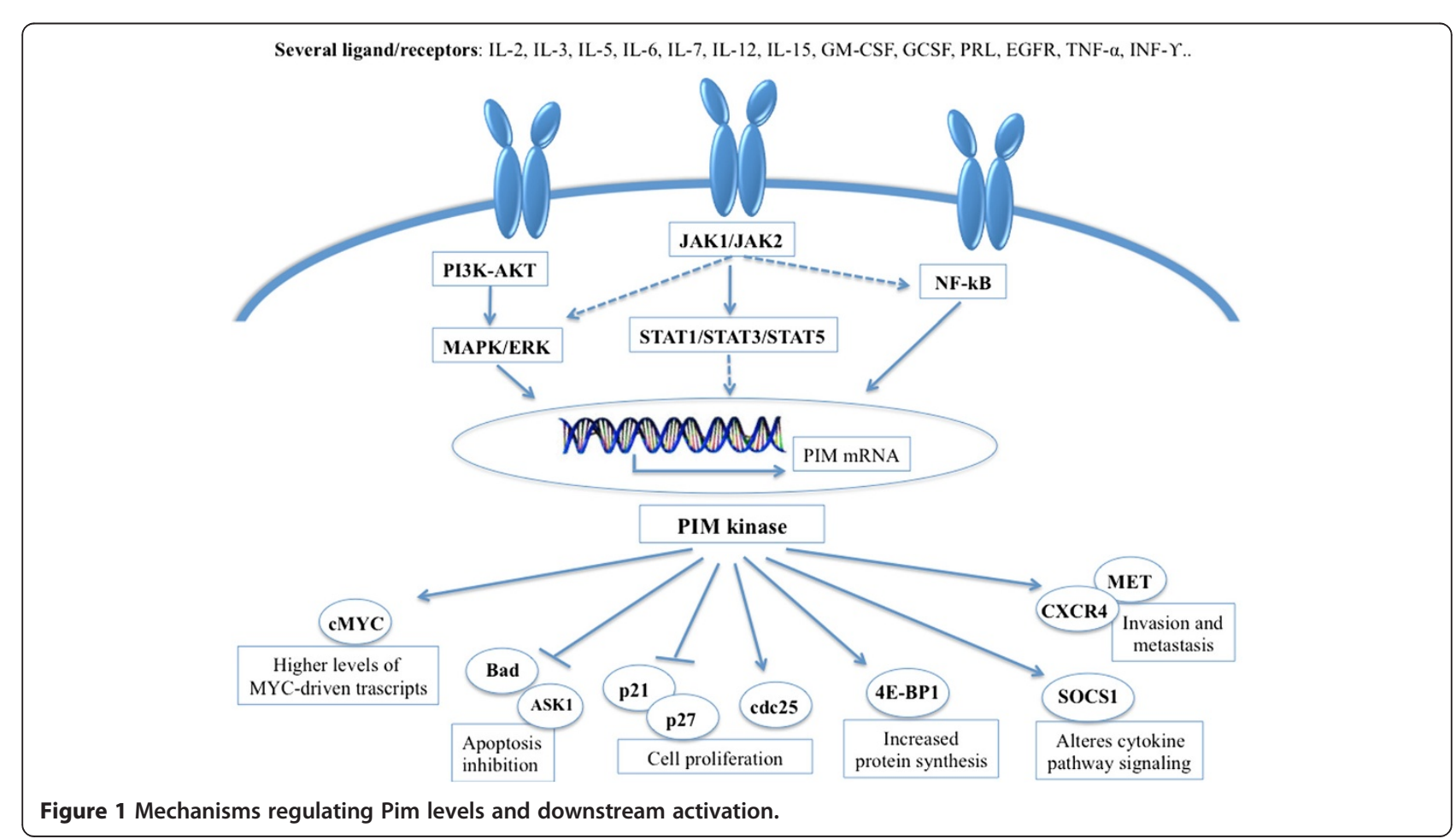


Finally, Pim-2 maintains high levels of NFkB required for its antiapoptotic function. Indeed, transcriptional targets of the NF-kB include many genes associated with survival, such as Bcl-2 and Bcl-xL. Hammerman et al. demonstrated that Pim-2 activates NF-kB by inducing phosphorylation of Cot, a serine/threonine kinase downstream to both MAPK/ERK and NF-kB signaling pathways [49]. Furthermore, Pim-1 phosphorylates RelA/p65, the main subunit of NF-kB, preventing its degradation from ubiquitin-mediated proteolysis. Knocking down Pim-1 severely impaired cell survival, at least in part, by interfering RelA/p65 activation [50].

\section{Cell cycle regulation}

Pim kinases are involved in cell proliferation through the phosphorylation of the cyclin-dependent kinase inhibitors p21 at Threonine (Thr)145 and Ser146 [51,52], p27 at Thr157 and Thr198 [53]. Phosphorylation of p21 induces its translocation from the nucleus to the cytoplasm, resulting in cell proliferation and survival $[54,55]$. Overexpression of Pim-2 leads to enhanced levels and stability of p21, while knockdown of Pim-2 results in reduced levels of p21 [52]. Notably, treatment with pan-Pim inhibitor lowered not only Pim-2 kinase activity, but also p21 phosphorylation [56]. An inverse relation seems to exist between Pim and p27 levels. Morishita et al. have demonstrated that phosphorylation of p27 by Pim kinases prompts its binding to $14-3-3$ proteins and subsequent nuclear exclusion and degradation of p27. Furthermore, Pim kinases seem to down-regulate p27 at the transcriptional level by inactivating Forkhead transcription factors [53]. In addition, Pim-1 seems to influence cell cycle phase transition by phosphorylating critical tyrosine phosphatases: Cdc25A for the $\mathrm{G} 1 / \mathrm{S}$ and $\mathrm{Cdc} 25 \mathrm{C}$, and the $\mathrm{Cdc} 25 \mathrm{C}$-associated kinase (C-TAK)1 for the G2/M $[57,58]$.

In further support of its role in the cell cycle, Pim-1 showed to phosphorylate the nuclear mitotic apparatus protein $(\mathrm{NuMa})$, that is essential for mitotic spindle formation and aids in chromosome separation. Pim-1 seems to contribute to maintenance of a stable connection between NuMA, dynein/dynactin and the pericentric protein HP1 $\beta$, a complex that is necessary for mitosis. Notably, the 'kinase-dead' mut-Pim-1-GFP fusion protein hinders the progression of mitosis and results in rapid cell death by apoptosis [59].

\section{Cell Proliferation}

Pim-1 and/or Pim-2 are significant downstream targets of transcription factors STAT 3 and STAT 5 [60]. Pim kinases in turn are able to influence the JAK/STAT pathway through their direct interaction and phosphorylation of Suppressor of Cytokine Signalling (SOCS)-1, a wellknown regulator of this signaling pathway $[61,62]$. The modulation of SOCS1 by Pim kinases seems to have a critical role in $\mathrm{V}$-Abl-induced tumorgenesis. In the xenograft model $\mathrm{v}$-Abl was not able to transform bone marrow cells deficient in the Pim-1/Pim-2 model, but it partially succeeded in its transformation activity combining the triple knockout of Pim-1, Pim-2 and SOCS1 [63]. Although Pim kinases are pro-oncogenic proteins, they are not sufficient to initiate disease [64] and therefore a cooperation between Pim-1 and c-Myc is required for promoting STAT3-mediated cell cycle progression [65]. Both Pim-1 and Pim-2 phosphorylate c-Myc, increasing its stability and consequently its transcriptional activity [66]. Recently, it has been demonstrated that this cooperation takes place also at the transcriptional level through Pim-mediated phosphorylation of preacetylated hystone H3 on Ser10 (H3S10) [67]. The H3S10 phospholytation is required to mediate the interaction with 14-3-3 proteins [68] and the ensuing recruitment of the histone acetyltransferase MOF, which acetylates histone $\mathrm{H} 4$, generating a nucleosome platform for bromodomain-containing protein 4 (BRD4) binding. Thereafter, the positive transcription elongation factor $\mathrm{b}(\mathrm{P}-\mathrm{TEF} \mathrm{b})$ is recruited inducing the phosphorylation of RNA polymerase II (Pol II) and the release of stalled Pol II, which activates transcriptional elongation [69]. However, Pim kinases contribute for about 20\% of Myc-induced gene expression [67]. c-Myc stability is mainly controlled by the ubiquitin-proteasome system, in particular by Fbxw-7 [70]. An inverse proportion exists between Fbxw-7 and c-Myc levels [71,72], consequently Fbxw-7 deletion was associated with c-Myc accumulation and aberrant cell cycle entry [73,74]. Mutation of Fbxw-7 has been found in solid [75-78] and blood malignancies [79]. In addition, also the control of miRNA expression plays an important role in Myc-mediated tumorgenesis. Several studies found that c-Myc repressed a wide range of miRNAs by directly binding the promoter of these miRNAs [80,81], favoring Myc-mediated tumorgenesis and conferring a more aggressive feature.

Pim activity is synergistic with another independent prosurvival pathway, phosphoinositide-3 Kinase/Akt/mammalian (PI3K/Akt/mTOR) [82]. Pim-2, but not Pim-1, has been identified as the principal kinase that phosphorylates the translational repressor 4E-BP1 and p70S6 independently of the PI3K/Akt/mTOR pathway [2]. Indeed, the activation of Pim-2 revealed an important role in cell growth resistant to rapamicin, an mTOR inhibitor [83]. Therefore, suppressing Pim-2 is important to treat rapamycinresistant tumors.

\section{Cell migration}

The Pim proteins also revealed an involvement in signaling pathways that control cell migration. Pim-1 plays a significant role on MET expression, the receptor for hepatocyte growth factor (HGF) involved in signaling normal and tumor cell migration and invasion. Pim-1 controls the 
translation of MET by phosphorylation of eukaryotic initiation factor $4 \mathrm{~B}$ (eIF4B) at Ser406 and the use of Pim inhibitor has been associated with a significant decrease of MET expression [84].

In addition, Pim-1 showed an influence on the chemokine ligand 12 (CXCL12)/chemokine (C-X-C motif) receptor 4 (CXCR4) expression, a ligand/receptor system with a crucial role in normal homeostasis [85], especially in the hematopoietic stem cells grafting $[86,87]$. Extracellular signal-regulated protein kinase 1/2 (ERK1/2) [88,89], PI3K [90] and Syk [91] transduction pathways showed to be differently implicated in CXCR4-mediated migration and proliferation. The imbalance of CXCL12/CXCR4 axis is implicated in cancer progression and spreading of tumor-initiating cells [92]. In vitro experiments suggested that Pim-1 might regulate CXCR-4 expression through phosphorylation of the Ser339 in the intracellular domain involved in receptor internalization [93]. Pim-1 overexpression has proved to correlate with CXCR4 levels also in leukemic blasts. Interestingly Pim inhibitor treatment led to downregulation of CXCR4 surface expression in primary cells, inducing impairment of Pim-mediated cell survival and block of CXCR4-mediated interaction of cells with their protective microenvironment [93,94].

\section{Expression levels of PIM kinases in hematologic cancer} Overexpression of Pim kinases has been observed in different human cancers, but mainly in haematological malignancies [20]. Initially, overexpression of Pim-1 was found in human myeloid and lymphoid leukemias [33,34]. In acute myeloid leukemia (AML) increased levels of Pim-1 have been associated with aberrant expression of the mixed-line-age leukemia (MLL) gene [95] as a consequent activation of tyrosine-kinase receptor FLT3 or the transcriptional regulator Hoxa9 [11,96-98].

Almost half of diffuse large B-cell lymphoma (DLBCL) tissues showed an increased expression of Pim kinases $[99,83]$, which is even more frequent in the activated B-cell
(ABC) subtype due to the constitutive activation of JAK/ STAT3 signaling [14]. Brault et al. proved a strong correlation between level expression of Pim kinases, STAT signaling, higher proliferative rate, and more advanced disease stage. Therefore, these findings suggest the possible role of Pim kinases as markers for DLBCL progression [100].

Increased levels of Pim-2 were also found in mantle cell lymphoma (MCL), follicular lymphoma (FL), marginal zone lymphoma-MALT type (MZL-MALT), chronic lymphocytic leukemia (CLL), nodal marginal zone lymphoma (NMZL) [17,101,102] and multiple myeloma [103].

\section{Pim kinases as therapeutic targets}

Pim kinases are attractive therapeutic targets since they are often aberrantly expressed in several hematologic disorders and because they contribute to cellular proliferation and migration. A large number of new molecules have been produced so far. While most of them are specific inhibitors of Pim-1, only few are able to inhibit all Pim isoforms $[104,105]$ (Table 1). However, because of the overlapping functions of these kinases, a pan-Pim inhibitor resulted to be more effective than a selective one [106].

A first generation of Pim-inhibitors (SGI-1773, SGI-1776) demonstrated high antitumor activity both in vitro and in vivo in different hematological tumors [107-109]. SGI-1776 is an imadizaopyridazine with nanomolar activity not only on the three Pim kinases, but also on Flt3 and Haspin. Therefore, the real contribution of Pim inhibition to the efficacy of this compound is unclear. In contrast to SGI-1773, SGI-1776 has shown to induce an almost complete suppression of Cyclin D1, cMYC and MCL1. In addition, SGI-1776 has been demonstrated to overcome Pim2-mediated rapamycin resistance without increased toxicities in a mouse model [110]. Based on these positive results, a phase I clinical trial recruiting castrationresistant prostate cancer or relapsed/refractory nonHodgkin lymphoma patients was conducted. However, due to unexpected severe cardiotoxicity the trial was ended

Table 1 Novel Pim-Inhibitors in hematologic malignancies

\begin{tabular}{|c|c|c|c|c|}
\hline Compound & Class & PIM inhibition selectivity & Development & Disease \\
\hline SGI-1776 & imadizaopyridazine & $\begin{array}{l}\text { IC50: } 7 \text { nM PIM1, } 363 \text { nM PIM2, } 69 \text { nM PIM3, } \\
44 \text { nM FLT-3 and } 34 \text { nM Haspin [107]. }\end{array}$ & $\begin{array}{l}\text { Failure in phase I clinical } \\
\text { trials by cardiotoxicity }\end{array}$ & $\begin{array}{l}\text { Non-Hodgkin } \\
\text { lymphoma }\end{array}$ \\
\hline \multirow[t]{2}{*}{ SMI4a } & \multirow[t]{2}{*}{ benzylidene-thiazolidene-2,4-dione } & IC50: 21 nM PIM1, 100 nM PIM2 [113]. & \multirow[t]{2}{*}{ Preclinical } & \multirow{2}{*}{$\begin{array}{l}\text { Acute myeloid } \\
\text { leukemia }\end{array}$} \\
\hline & & Selective vs. 56 kinases [114]. & & \\
\hline LGB321 & $\begin{array}{l}\text { 3-(S)-amino-piperidine pyridyl } \\
\text { carboxamide }\end{array}$ & $\begin{array}{l}\text { IC50: } 0.001 \text { nM PIM1, } 0.0021 \text { nM PIM2, } \\
\text { and } 0.0008 \text { nM PIM3 [106]. }\end{array}$ & $\begin{array}{l}\text { Recruiting patients for } \\
\text { clinical trials }\end{array}$ & Multiple myeloma \\
\hline AZD1897 & & IC50: 3 nM PIM1,2 and 3 [115]. & Preclinical & $\begin{array}{l}\text { Acute myeloid } \\
\text { leukemia }\end{array}$ \\
\hline SEL24-B58 & Benzoimidazol & $\begin{array}{l}\text { IC50: } 31 \text { nM PIM1, } 154 \text { nM PIM2, } 152 \text { nM PIM3. } \\
\text { Selective in a panel of } 299 \text { kinases with the } \\
\text { exception of haspin, HIPK and CLK kinases [117]. }\end{array}$ & Preclinical & $\begin{array}{l}\text { Leukemic monocyte } \\
\text { lymphoma }\end{array}$ \\
\hline AZD1208 & thiazolidene & $\begin{array}{l}\text { IC50: Pim-1 } 0.4 \text { nM, Pim-2 } 5.0 \text { nM and } \\
\text { Pim-3 } 1.9 \text { nM [115]. }\end{array}$ & $\begin{array}{l}\text { Recruiting patients for } \\
\text { clinical trials }\end{array}$ & $\begin{array}{l}\text { Acute myeloid } \\
\text { leukemia }\end{array}$ \\
\hline
\end{tabular}


early. (NCT00848601) This event could be related to the inhibition of Pim-1, which has been demonstrated to play an important role in the promotion of cardioprotective signaling and inhibiting pathological injury $[111,112]$.

Second generation Pim-inhibitors were designed to increase specificity and to eliminate cardiotoxicity. SMI4a is a benzylidene-thiazolidene-2,4-dione inhibiting PIM1 (24 $\mathrm{nM}$ ) and PIM2 (100 nM) [113]. This molecule is able to induce G1 arrest through a marked increase of p27 and consequently inhibition of cdk2. In a mouse model SMI4a induced a delay in tumor growth without important toxicity [113]. SMI4a demonstrated synergy with the mTOR inhibitor rapamycin by downregulating p4EBP1 and blocking proliferation in AML cells [114]. Since SMI4a increases phosphorylation of ERK1/2, its association with a MEK1/2 inhibitor also showed a good synergistic activity leading to a higher death rate of precursor T-cell lymphoblastic lymphoma cells [113].

LGB321 is a 3-(S)-amino-piperidine pyridyl carboxamide, ATP-competitive inhibitor of all three Pim kinases with a $50 \%$ inhibitory concentration (IC50) for Pim-1, Pim-2 and Pim-3 of 0.001, 0.002 and $0.0008 \mathrm{nM}$, respectively. LGB321 was tested in different hematologic cell lines such as ALL, AML, multiple myeloma and B-cell NHL. Among all studied cell lines, the multiple myeloma subtype was the most sensitive with IC50 values in the picomolar range. LGB321 efficacy and safety profiles were also confirmed in vivo models [106]. Based on these data, a phase I clinical trial evaluating the LGB321 activity in relapse/refractory myeloma is ongoing (NCT02144038).

AZD1897 is an ATP-competitive pan-Pim inhibitor with IC50 of $3 \mathrm{nM}$ against Pim-1, 2 and 3 [115], recently evaluated in treatment of AML. In vitro studies demonstrated a limited activity of AZD1897 as a single agent, but a strong synergy in combination with the AKT-inhibitor AZD5363. This association led to a greater cytotoxic activity as well as a decreased downstream mTOR-targets (p4EBP1, pS6 kinase) and MCL1 levels with respect to the single agent therapy [116]. Based on the remarkable antileukemic activity of AZD1897 combined with AKT inhibition future clinical trials are warranted.

SEL24-B58 is able to inhibit all three Pim kinases already at picomolar dose (IC50 values are: Pim-1 $31 \mathrm{nM}$, Pim-2 $154 \mathrm{nM}$ and Pim-3 $152 \mathrm{nM}$ ). In vitro SEL24-B58 reduced Mcl-1 levels, demonstrating synergy in combination with the Bcl2-family inhibitor ABT-737 in leukemic monocyte cells. The combination with JAK1/2 inhibitor (Cyt387) in lymphoblastic leukemia cells resulted in a synergistic antiproliferative activity as well. A Xenograft model confirmed the efficacy of SEL24-B58 at a concentration of $150 \mathrm{mg} / \mathrm{kg}$ with a completed arrest of tumor growth after 17 days of treatment and no toxicity [117].

AZD1208 is a thiazolidene, highly selective for Pim-1, Pim-2 and Pim3 with a low nanomolar activity in cells
(IC50 of $0.4 \mathrm{nM}$ for Pim-1, 5.0 nM for Pim-2, and 1.9 $\mathrm{nM}$ for Pim-3) [115]. AZD1208 demonstrated in vitro and in vivo activity against AML. A significant growth inhibition was evident in a dose-dependent manner. Indeed, AZD1208 led to decreased phosphorylation of Bad, $4 \mathrm{EBP} 1, \mathrm{p} 70 \mathrm{S6K}$, and S6, as well as increased cleaved caspase 3 and p27 [32]. Notably, it showed to be active in Flt3-ITD primary tumor cells without the off-target inhibition activity [118] unlike previous PIM inhibitors $[108,109,119]$. Based on these interesting data, AZD1208 is currently being evaluated in phase 1 clinical trials. (NCT01489722, NCT01588548).

\section{Conclusion}

Pim kinases create a wide interest in oncology due to their overexpression in cancer and association with enhanced tumor growth and chemo-resistance. Given the close advent of Pim inhibitors in clinic, it is important to find their most efficient application. First of all biomarker identification might allow to select the patients and follow the course of treatment. So far, no genetic markers have been established to guide therapeutical decision. Therefore, it may be worth improving the knowledge of Pimdependent gene expression and verify the existence of a correlation between high levels of different subsets of Pim-regulated genes and increased sensitivity to treatment. Another open question is whether Pim kinase inhibitors should be used as monotherapy or in combination. Preclinical data have shown that Pim inhibitors are effective drugs when used as single agents. However, their positive effect was even more pronounced when they were combined with chemo- or other target-therapies (Pi3k/ $\mathrm{AKT} / \mathrm{mTOR}$ inhibitor). In addition, these inhibitors demonstrated to significantly reverse drug resistant phenotypes in preclinical models. It is necessary to wait until the conclusion of clinical trials using Pim kinases inhibitors to see if tumor cells will develop resistance through other signaling pathways. Finally, evaluation of toxicity will be important as well due to the difficulty in finding the right balance between sufficient inhibition and acceptable toxicity when multiple signaling inhibitors are combined.

In the near future research should focus on the activity of Pim kinases and their involvement in resistance mechanisms in order to allow for a more efficient treatment and application.

\section{Abbreviations}

PIM: Proviral insertion in murine; IL: Interleukin; GM-CSF: Granulocyte-macrophage colony-stimulating factor; G-CSF: Granulocyte-colony stimulating factor; ABL: Ableson; JAK2: Janus Kinase 2; FLT3: FMS-like tyrosine kinase 3 ;

MuLV: Murine leukemia virus; MCV: Mean cell volume; HSCs: Hematopoietic stem cells; Bad: Bcl-2-associated agonist of cell death; Ser: Serine; ASK1: Apoptosis signaling kinase 1; Thr: Threonine; C-TAK: Cdc25C-associated kinase; SOCS: Suppressor of Cytokine Signalling; H3S10: Histone H3 phosphorylate at Ser10; BRD4: Bromodomain-containing protein 4; P-TEFb: Positive transcription elongation factor b; Pol II: Polymerase II; PI3K/Akt/mTOR: Phosphoinositide-3 Kinase/Akt/mammalian; elF4B: Eukaryotic initiation factor 4B; CXCL12/ 
CXCR4: Chemokine ligand 12/chemokine C-X-C motif receptor 4; ERK1/2: Extracellular signal-regulated protein kinase 1/2; MLL: Mixed-line-age leukemia; ABC: Activated B-cell; MCL: Mantle cell lymphoma; FL: Follicular lymphoma; MZL-MALT: Marginal zone lymphoma-MALT type; CLL: Chronic lymphocytic leukemia; NMZL: Nodal marginal zone lymphoma; IC50: 50\% inhibitory concentration.

\section{Competing interests}

The authors have no conflicts of interest regarding the publication of this article.

\section{Authors' contributions}

MP revised the literature and wrote the manuscript; CS and MM were involved in revising the manuscript critically for important intellectual content. All authors read and approve the final manuscript.

\section{Acknowledgements}

This article did not receive any specific grant from any funding agency in the public, commercial or not-for-profit sector.

\section{Author details}

'Department of Human Pathology, University of Messina, Via Consolare Valeria, 98125 Messina, Italy. ${ }^{2}$ Department of Biological and Environmental Sciences, University of Messina, Messina, Italy. ${ }^{3}$ Department of Hematology, Hospital S. Maurizio, Bolzano/Bozen, Italy. ${ }^{4}$ Department of Internal Medicine $\checkmark$, Hematology \& Oncology, Medical University Innsbruck, Innsbruck, Austria.

Received: 22 September 2014 Accepted: 4 December 2014

Published online: 10 December 2014

\section{References}

1. Nawijn MC, Alendar A, Berns A: For better or for worse: the role of Pim oncogenes in tumorigenesis. Nat Rev Cancer 2011, 11:23-34.

2. Fox CJ, Hammerman PS, Cinalli RM, Master SR, Chodosh LA, Thompson CB: The serine/threonine kinase Pim- 2 is a transcriptionally regulated apoptotic inhibitor. Genes Dev 2003, 17:1841-1854.

3. Qian KC, Wang L, Hickey ER, Studts J, Barringer K, Peng C, Kronkaitis A, Li J, White A, Mische S, Farmer B: Structural basis of constitutive activity and a unique nucleotide binding mode of human Pim-1 kinase. J Biol Chem 2005, 280:6130-6137.

4. Allen JD, Verhoeven E, Domen J, van der Valk M, Berns A: Pim-2 transgene induces lymphoid tumors, exhibiting potent synergy with c-myc. Oncogene 1997, 15:1133-1141.

5. Dautry F, Weil D, Yu J, Dautry-Varsat A: Regulation of pim and myb mRNA accumulation by interleukin 2 and interleukin 3 in murine hematopoietic cell lines. J Biol Chem 1988, 263:17615-17620.

6. Lilly M, Le T, Holland P, Hendrickson SL: Sustained expression of the pim-1 kinase is specifically induced in myeloid cells by cytokines whose receptors are structurally related. Oncogene 1992, 7:727-732.

7. Pratt WB: The role of the hsp90-based chaperone system in signal transduction by nuclear receptors and receptors signaling via MAP kinase. Annu Rev Pharmacol Toxicol 1997, 37:297-326.

8. Mizuno K, Shirogane T, Shinohara A, Iwamatsu A, Hibi M, Hirano T: Regulation of Pim-1 by Hsp90. Biochem Biophys Res Commun 2001 281:663-669.

9. Nieborowska-Skorska M, Hoser G, Kossev P, Wasik MA, Skorski T: Complementary functions of the antiapoptotic protein $\mathrm{A} 1$ and serine/threonine kinase pim-1 in the BCR/ABL-mediated leukemogenesis. Blood 2002, 99:4531-4539.

10. Wernig G, Gonneville JR, Crowley BJ, Rodrigues MS, Reddy MM, Hudon HE, Walz C, Reiter A, Podar K, Royer Y, Constantinescu SN, Tomasson MH, Griffin JD, Gilliland DG, Sattler M: The Jak2V617F oncogene associated with myeloproliferative diseases requires a functional FERM domain for transformation and for expression of the Myc and Pim proto-oncogenes. Blood 2008, 111:3751-3759.

11. Kim KT, Baird K, Ahn JY, Meltzer P, Lilly M, Levis M, Small D: Pim-1 is up-regulated by constitutively activated FLT3 and plays a role in FLT3-mediated cell survival. Blood 2005, 105:1759-1767.

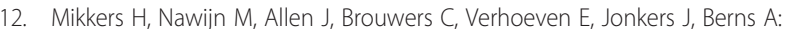
Mice deficient for all PIM kinases display reduced body size and impaired responses to hematopoietic growth factors. Mol Cell Biol 2004, 24:6104-6115.
13. Eichmann A, Yuan L, Bréant C, Alitalo K, Koskinen PJ: Developmental expression of pim kinases suggests functions also outside of the hematopoietic system. Oncogene 2000, 19:1215-1224.

14. Bachmann M, Möröy T: The serine/threoninekinasePim-1. Int J Biochem Cell Biol 2005, 37:726-730.

15. Feldman JD, Vician L, Crispino M, Tocco G, Marcheselli VL, Bazan NG, Baudry M Herschman HR: KID-1, a protein kinase induced by depolarization in brain. J Biol Chem 1998, 273:16535-16543.

16. Alizadeh AA, Eisen MB, Davis RE, Ma C, Lossos IS, Rosenwald A, Boldrick JC, Sabet H, Tran T, Yu X, Powell Jl, Yang L, Marti GE, Moore T, Hudson J Jr, Lu L, Lewis DB, Tibshirani R, Sherlock G, Chan WC, Greiner TC, Weisenburger DD, Armitage JO, Warnke R, Levy R, Wilson W, Grever MR, Byrd JC, Botstein D, Brown PO, Staudt LM: Distinct types of diffuse large B-cell lymphoma identified by gene expression profiling. Nature 2000, 403:503-511.

17. Cohen AM, Grinblat B, Bessler H, Kristt D, Kremer A, Schwartz A, Halperin M, Shalom S, Merkel D, Don J: Increased expression of the hPim-2 gene in human chronic lymphocytic leukemia and non-Hodgkin lymphoma. Leuk Lymphoma 2004, 45:951-955.

18. Wingett D, Long A, Kelleher D, Magnuson NS: Pim-1 proto-oncogene expression in anti-CD3- mediated T-cell activation is associated with pro- tein kinase $\mathrm{C}$ activation and is independent of Raf-1. J Immunol 1996, 156:549-557.

19. Cibull TL, Jones TD, Li L, Eble JN, Ann Baldridge L, Malott SR, Luo Y, Cheng L: Overexpression of Pim-1 during progression of prostatic adenocarcinoma. J Clin Pathol 2006, 59:285-288.

20. Shah N, Pang B, Yeoh KG, Thorn S, Chen CS, Lilly MB, Salto-Tellez M: Potential roles for the PIM1 kinase in human cancer - a molecular and therapeuticappraisal. Eur J Cancer 2008, 44:2144-2151.

21. Van Lohuizen M, Verbeek S, Krimpenfort P, Domen J, Saris C, Radaszkiewicz T, Berns A: Predisposition to lymphomagenesis in pim-1 transgenic mice: cooperation with c-myc and $\mathrm{N}$-myc in murine leukemia virus-induced tumors. Cell 1989, 56:673-682

22. van Lohuizen M, Verbeek S, Scheijen B, Wientjens E, van der Gulden $H$, Berns $A$ : Identification of cooperating oncogenes in $E$ mu-myc transgenic mice by provirus tagging. Cell 1991, 65:737-752.

23. Berns A: Tumorigenesis in transgenic mice: identification and characterization of synergizing oncogenes. J Cell Biochem 1991, 47:130-135.

24. Verbeek S, van Lohuizen M, van der Valk M, Domen J, Kraal G, Berns A: Mice bearing the E mu-myc and E mu-pim-1 transgenes develop pre-B-cell leukemia prenatally. Mol Cell Biol 1991, 11:1176-1179.

25. Kim J, Roh M, Abdulkadir SA: Pim1 promotes human prostate cancer cell tumorigenicity and c-MYC transcriptional activity. BMC Cancer 2010, 10:248.

26. Shinto $Y$, Morimoto M, Katsumata M, Uchida A, Aozasa K, Okamoto M, Kurosawa T, Ochi T, Greene Ml, Tsujimoto Y: Moloney murine leukemia virus infection accelerates lymphomagenesis in E mu-bcl-2 transgenic mice. Oncogene 1995, 11:1729-1736.

27. Baron BW, Anastasi J, Hyjek EM, Bies J, Reddy PL, Dong J, Joseph L, Thirman MJ, Wroblewski K, Wolff L, Baron JM: PIM1 gene cooperates with human BCL6 gene to promote the development of lymphomas. Proc Natl Acad Sci U S A 2012, 109:5735-5739.

28. Blyth K, Terry A, Mackay N, Vaillant F, Bell M, Cameron ER, Neil JC, Stewart M: Runx2: a novel oncogenic effector revealed by in vivo complementation and retroviral tagging. Oncogene 2001, 20:295-302.

29. Feldman BJ, Reid TR, Cleary ML: Pim1 cooperates with E2a-Pbx1 to facilitate the progression of thymic lymphomas in transgenic mice. Oncogene 1997, $15: 2735-2742$

30. Jonkers J, Korswagen HC, Acton D, Breuer M, Berns A: Activation of a novel proto-oncogene, Frat1, contributes to progression of mouse T-cell lymphomas. EMBO J 1997, 16:441-450.

31. An N, Kraft AS, Kang Y: Abnormal hematopoietic phenotypes in Pim kinase triple knockout mice. J Hematol Oncol 2013, 29:6-12.

32. Fox CJ, Hammerman PS, Thompson CB: The Pim kinases control rapamycin-resistant T cell survival and activation. J Exp Med 2005, 201:259-266.

33. Wang Z, Bhattacharya N, Weaver M, Petersen K, Meyer M, Gapter L, Magnuson NS: Pim-1: A serine/threonine kinase with a role in cell survival, proliferation, differentiation and tumorigenesis. J Vet Sci 2001, 2:167-179.

34. Cuypers HT, Selten G, Berns A, van Kessel AH G: Assignment of the human homologue of Pim-1, a mouse gene implicated in leukemogenesis, to the pter-q12 region of chromosome 6. Hum Genet 1986, 72:262-265. 
35. Aho TL, Sandholm J, Peltola KJ, Mankonen HP, Lilly M, Koskinen PJ: Pim-1 kinase promotes inactivation of the pro-apoptotic Bad protein by phosphorylating it on the Ser112 gatekeeper site. FEBS Lett 2004 571:43-49.

36. Macdonald A, Campbell DG, Toth R, McLauchlan H, Hastie CJ, Arthur JS: Pim kinases phosphorylate multiple sites on Bad and promote 14-3-3 binding and dissociation from BCl-XL. BMC Cell Biol 2006, 7:1.

37. Yan B, Zemskova M, Holder S, Chin V, Kraft A, Koskinen PJ, Lilly M: The PIM-2 kinase phosphorylates BAD on serine 112 and reverses BAD-induced cell death. J Biol Chem 2003, 278:45358-45367.

38. Li YY, Popivanova BK, Nagai Y, Ishikura H, Fujii C, Mukaida N: Pim-3, a proto-oncogene with serine/ threonine kinase activity, is aberrantly expressed in human pancreatic cancer and phosphorylates bad to block bad-mediated apoptosis in human pancreatic cancer cell lines. Cancer Res 2006, 66:6741-6747.

39. Gu JJ, Wang Z, Reeves R, Magnuson NS: PIM1 phosphorylates and negatively regulates ASK1-mediated apoptosis. Oncogene 2009, 28:4261-4271.

40. Hogan C, Hutchison C, Marcar L, Milne D, Saville M, Goodlad J, Kernohan N, Meek D: Elevated levels of oncogenic protein kinase Pim-1 induce the p53 pathway in cultured cells and correlate with increased Mdm2 in mantle cell lymphoma. J Biol Chem 2008, 283:18012-18023.

41. Zhou BP, Liao Y, Xia W, Zou Y, Spohn B, Hung MC: HER-2/neu induces p53 ubiquitination via Akt-mediated MDM2 phosphorylation. Nat Cell Biol 2001, 3:973-982

42. Mayo LD, Donner DB: A phosphatidylinositol 3-kinase/Akt pathway promotes translocation of Mdm2 from the cytoplasm to the nucleus. Proc Natl Acad Sci U S A 2001, 98:11598-11603.

43. Ashcroft M, Ludwig RL, Woods DB, Copeland TD, Weber HO, MacRae EJ, Vousden KH: Phosphorylation of HDM2 by Akt. Oncogene 2002, 21:1955-1962.

44. Gottlieb TM, Leal JF, Seger R, Taya Y, Oren M: Cross-talk between Akt, p53 and Mdm2: possible implications for the regulation of apoptosis. Oncogene 2002, 21:1299-1303.

45. Jackson MW, Patt LE, LaRusch GA, Donner DB, Stark GR, Mayo LD: Hdm2 nuclear export, regulated by insulin-like growth factor-l/MAPK/p90Rsk signaling, mediates the transformation of human cells. J Biol Chem 2006, 281:16814-16820.

46. Weber HO, Ludwig RL, Morrison D, Kotlyarov A, Gaestel M, Vousden KH: HDM2 phosphorylation by MAPKAP kinase 2. Oncogene 2005, 24:1965-1972.

47. Stott FJ, Bates S, James MC, McConnell BB, Starborg M, Brookes S, Palmero I, Ryan $\mathrm{K}$, Hara E, Vousden $\mathrm{KH}$, Peters $\mathrm{G}$ : The alternative product from the human CDKN2A locus, p14(ARF), participates in a regulatory feedback loop with p53 and MDM2. EMBO J 1998, 17:5001-5014.

48. Llanos S, Clark PA, Rowe J, Peters G: Stabilization of p53 by p14ARF without relocation of MDM2 to the nucleolus. Nat Cell Biol 2001 3:445-452.

49. Hammerman PS, Fox CJ, Cinalli RM, Xu A, Wagner JD, Lindsten T, Thompson CB: Lymphocyte transformation by Pim-2 is dependent on nuclear factor-kappaB activation. Cancer Res 2004, 64:8341-8348.

50. Nihira K, Ando Y, Yamaguchi T, Kagami Y, Miki Y, Yoshida K: Pim-1 controls NF-kappaB signalling by stabilizing RelA/p65. Cell Death Differ 2010, 17:689-698.

51. Wang Z, Bhattacharya N, Mixter PF, Wei W, Sedivy J, Magnuson NS: Phosphorylation of the cell cycle inhibitor p21Cip1/WAF1 by Pim-1 kinase. Biochim Biophys Acta 2002, 1593:45-55.

52. Wang Z, Zhang Y, Gu JJ, Davitt C, Reeves R, Magnuson NS: Pim-2 phosphorylation of p21(Cip1/WAF1) enhances its stability and inhibits cell proliferation in HCT116 cells. Int J Biochem Cell Biol 2010 42:1030-1038.

53. Morishita D, Katayama R, Sekimizu K, Tsuruo T, Fujita N: Pim kinases promote cell cycle progression by phosphorylating and down-regulating p27Kip1 at the transcriptional and posttranscriptional levels. Cancer Res 2008, 68:5076-5085.

54. Xia W, Chen JS, Zhou X, Sun PR, Lee DF, Liao Y, Zhou BP, Hung MC Phosphorylation/cytoplasmic localization of p21Cip1/WAF1 is associated with HER2/neu overexpression and provides a novel combination predictor for poor prognosis in breast cancer patients. Clin Cancer Res 2004, 10:3815-3824.

55. Zhou BP, Liao Y, Xia W, Spohn B, Lee MH, Hung MC: Cytoplasmic localization of p21Cip1/WAF1 by Akt-induced phosphorylation in HER-2/neuoverexpressing cells. Nat Cell Biol 2001, 3:245-252.
56. Mumenthaler SM, Ng PY, Hodge A, Bearss D, Berk G, Kanekal S, Redkar S, Taverna P, Agus DB, Jain A: Pharmacologic inhibition of Pim kinases alters prostate cancer cell growth and resensitizes chemoresistant cells to taxanes. Mol Cancer Ther 2009, 8:2882-2893.

57. Mochizuki T, Kitanaka C, Noguchi K, Muramatsu T, Asai A, Kuchino Y: Physical and functional interactions between Pim-1 kinase and Cdc25A phosphatase. Implications for the Pim-1-mediated activation of the c-Myc signaling pathway. J Biol Chem 1999, 274:18659-18666.

58. Bachmann M, Hennemann H, Xing PX, Hoffmann I, Moroy T: The oncogenic ser- ine/threonine kinase Pim-1 phosphorylates and inhibits the activity of Cdc25C-associated kinase 1 (C-TAK1): a novel role for Pim-1 at the G2/M cell cycle checkpoint. J Bio/ Chem 2004, 279:48319-48328.

59. Bhattacharya N, Wang Z, Davitt C, McKenzie IF, Xing PX, Magnuson NS: Pim-1 associates with protein complexes necessary for mitosis. Chromosoma 2002, 111:80-95.

60. Yip-Schneider MT, Horie M, Broxmeyer HE: Transcriptional induction of pim-1 protein kinase gene expression by interferon gamma and posttranscriptional effects on costimulation with steel factor. Blood 1995, 85:3494-3502.

61. Chen XP, Losman JA, Cowan S, Donahue E, Fay S, Vuong BQ, Nawijn MC, Capece D, Cohan VL, Rothman P: Pim serine/threonine kinases regulate the stability of Socs-1 protein. Proc Natl Acad Sci U S A 2002, 99:2175-2180.

62. Peltola KJ, Paukku K, Aho TL, Ruuska M, Silvennoinen O, Koskinen PJ: Pim-1 kinase inhibits STAT5-dependent transcription via its interactions with SOCS1 and SOCS3. Blood 2004, 103:3744-3750.

63. Chen JL, Limnander A, Rothman PB: Pim-1 and Pim-2 kinases are required for efficient pre-B-cell transformation by v-Abl oncogene. Blood 2008, 111:1677-1685.

64. Berns A, Mikkers $H$, Krimpenfort $P$, Allen J, Scheijen B, Jonkers J: Identification and characterization of collaborating oncogenes in compound mutant mice. Cancer Res 1999, 59(Suppl):1773-1777.

65. Shirogane T, Fukada T, Muller JM, Shima DT, Hibi M, Hirano T: Synergistic roles for Pim-1 and c-Myc in STAT3-mediated cell cycle progression and antiapoptosis. Immunity 1999, 11:709-719.

66. Zhang Y, Wang Z, Li X, Magnuson NS: Pim kinase-dependent inhibition of c-Myc degradation. Oncogene 2008, 27:4809-4819.

67. Zippo A, De Robertis A, Serafini R, Oliviero S: PIM1-dependent phosphorylation of histone $\mathrm{H} 3$ at serine 10 is required for MYC-dependent transcriptional activation and oncogenic transformation. Nat Cell Biol 2007, 9:932-944.

68. Winter S, Simboeck E, Fischle W, Zupkovitz G, Dohnal I, Mechtler K, Ammerer $G$, Seiser C: 14-3-3 proteins recognize a histone code at histone $\mathrm{H} 3$ and are required for transcriptional activation. EMBO J 2008, 27:88-99.

69. Zippo A, Serafini R, Rocchigiani M, Pennacchini S, Krepelova A, Oliviero S: Histone crosstalk between H3S10ph and H4K16ac generates a histone code that mediates transcription elongation. Cell 2009, 138:1122-1136.

70. Nakayama Kl, Nakayama K: Ubiquitin ligases: cell-cycle control and cancer. Nat Rev Cancer 2006, 6:369-381.

71. Matsumoto A, Onoyama I, Nakayama Kl: Expression of mouse Fbxw7 isoforms is regulated in a cell cycle- or p53-dependent manner. Biochem Biophys Res Commun 2006, 350:114-119.

72. Yoshida GJ, Saya H: Inversed relationship between CD44 variant and c-Myc due to oxidative stress-induced canonical Wnt activation. Biochem Biophys Res Commun 2014, 443:622-627.

73. Reavie L, Della Gatta G, Crusio K, Aranda-Orgilles B, Buckley SM, Thompson B, Lee E, Gao J, Bredemeyer AL, Helmink BA, Zavadil J, Sleckman BP, Palomero T, Ferrando A, Aifantis I: Regulation of hematopoietic stem cell differentiation by a single ubiquitin ligase-substrate complex. Nat Immuno/ 2010, 11:207-215.

74. Reavie L, Buckley SM, Loizou E, Takeishi S, Aranda-Orgilles B, Ndiaye-Lobry D, Abdel-Wahab O, Ibrahim S, Nakayama Kl, Aifantis I: Regulation of c-Myc ubiquitination controls chronic myelogenous leukemia initiation and progression. Cancer Cell 2013, 23:362-375

75. Kwak EL, Moberg KH, Wahrer DC, Quinn JE, Gilmore PM, Graham CA, Hariharan IK, Harkin DP, Haber DA, Bell DW: Infrequent mutations of Archipelago (hAGO, hCDC4, Fbw7) in primary ovarian cancer. Gynecol Oncol 2005, 98:124-128.

76. Strohmaier $\mathrm{H}$, Spruck $\mathrm{CH}$, Kaiser $\mathrm{P}$, Won KA, Sangfelt O, Reed SI: Human F-box protein hCdc4 targets cyclin E for proteolysis and is mutated in a breast cancer cell line. Nature 2001, 413:316-322.

77. Spruck CH, Strohmaier H, Sangfelt O, Muller HM, Hubalek M, Muller-Holzner E, Marth C, Widschwendter M, Reed SI: hCDC4 gene mutations in endometrial cancer. Cancer Res 2002, 62:4535-4539. 
78. Rajagopalan H, Jallepalli PV, Rago C, Velculescu VE, Kinzler KW, Vogelstein B, Lengauer C: Inactivation of hCDC4 can cause chromosomal instability. Nature 2004, 428:77-81.

79. Siu KT, Xu Y, Swartz KL, Bhattacharyya M, Gurbuxani S, Hua Y, Minella AC: Chromosome instability underlies hematopoietic stem cell dysfunction and lymphoid neoplasia associated with impaired Fbw7- mediated cyclin E regulation. Mol Cell Biol 2014, 34:3244-3258.

80. Chang TC, Yu D, Lee YS, Wentzel EA, Arking DE, West KM, Dang CV, Thomas-Tikhonenko A, Mendell JT: Widespread microRNA repression by Myc contributes to tumorigenesis. Nat Genet 2008, 40:43-50.

81. Liu L, Wang S, Chen R, Wu Y, Zhang B, Huang S, Zhang J, Xiao F, Wang M, Liang $Y$ : Myc induced miR-144/451 contributes to the acquired imatinib resistance in chronic myelogenous leukemia cell K562. Biochem Biophys Res Commun 2012, 425:368-373.

82. Hammerman PS, Fox CJ, Brinbaum MJ, Thompson CB: Pim and Akt oncogenes are independent regulators of hematopoietic cell growth and survival. Blood 2005, 105:4477-4483.

83. Schatz JH, Oricchio E, Wolfe AL, Jiang M, Linkov I, Maragulia J, Shi W, Zhang Z, Rajasekhar VK, Pagano NC, Porco JA Jr, Teruya-Feldstein J, Rosen N, Zelenetz AD, Pelletier J, Wendel HG: Targeting cap-dependent translation blocks converging survival signals by AKT and PIM kinases in lymphoma. J Exp Med 2011, 208:1799-1807.

84. Cen B, Xiong Y, Song JH, Mahajan S, DuPont R, McEachern K, DeAngelo DJ, Cortes JE, Minden MD, Ebens A, Mims A, LaRue AC, Kraft AS: The Pim-1 Protein Kinase Is an Important Regulator of MET Receptor Tyrosine Kinase Levels and Signaling. Mol Cell Biol 2014, 34:2517-2532.

85. Kucia M, Jankowski K, Reca R, Wysoczynski M, Bandura L, Allendorf D, Zhang J, Ratajczak J, Ratajczak M: CXCR4-SDF-1 signaling, locomotion, chemotaxis and adhesion. J Mol Histol 2004, 35:233-245.

86. Lapidot T, Dar A, Kollet O: How do stem cells find their way home? Blood 2005, 106:1901-1910.

87. Busillo JM, Benovic JL: Regulation of CXCR4 signaling. Biochim Biophys Acta 2007, 1768:952-963.

88. Boudot A, Kerdivel G, Lecomte S, Flouriot G, Desille M, Godey F, Leveque Tas P, Le Dréan Y, Pakdel F: COUP-TFI modifies CXCL12 and CXCR4 expression by activating EGF signaling and stimulates breast cancer cell migration. BMC Cancer 2014, 14:407.

89. Matteucci E, Locati M, Desiderio MA: Hepatocyte growth factor enhances CXCR4 expression favoring breast cancer cell invasiveness. Exp Cell Res 2005, 310:176-185

90. Chetram MA, Don-Salu-Hewage AS, Hinton CV: ROS enhances CXCR4-mediated functions through inactivation of PTEN in prostate cancer cells. Biochem Biophys Res Commun 2011, 410:195-200.

91. Matsusaka S, Tohyama Y, He J, Shi Y, Hazama R, Kadono T, Kurihara R, Tohyama K, Yamamura H: Protein-tyrosine kinase, Syk, is required for CXCL12-induced polarization of B cells. Biochem Biophys Res Commun 2005, 328:1163-1169.

92. Croker AK, Allan AL: Cancer stem cells: implications for the progression and treatment of metastatic disease. J Cell Mol Med 2008, 12:374-390.

93. Grundler R, Brault L, Gasser C, Bullock AN, Dechow T, Woetzel S, Pogacic V, Villa A, Ehret S, Berridge G, Spoo A, Dierks C, Biondi A, Knapp S, Duyster J, Schwaller J: Dissection of PIM serine/threonine kinases in FLT3-ITDinduced leukemogenesis reveals PIM1 as regulator of CXCL12-CXCR4-mediated homing and migration. J Exp Med 2009, 206:1957-1970.

94. Decker S, Finter J, Forde AJ, Kissel S, Schwaller J, Mack TS, Kuhn A, Gray N, Follo M, Jumaa H, Burger M, Zirlik K, Pfeifer D, Miduturu CV, Eibel H, Veelken H, Dierks C: PIM kinases are essential for chronic lymphocytic leukemia cell survival (PIM2/3) and CXCR4-mediated microenvironmental interactions (PIM1). Mol Cancer Ther 2014, 13:1231-1245.

95. Chen W, Kumar AR, Hudson WA, Li Q, Wu B, Staggs RA, Lund EA, Sam TN, Kersey JH: Gene dosage and critical target cells. Cancer Cell 2008, 13:432-440.

96. Mizuki M, Schwable J, Steur C, Choudhary C, Agrawal S, Sargin B, Steffen B, Matsumura I, Kanakura Y, Böhmer FD, Müller-Tidow C, Berdel WE, Serve H: Suppression of myeloid transcription factors and induction of STAT response genes by AML-specific Flt3 mutations. Blood 2003, 101:3164-3173.

97. Hu YL, Passegue E, Fong S, Largman C, Lawrence HJ: Evidence that the Pim1 kinase gene is a direct target of HOXA9. Blood 2007, 109:4732-4738.

98. Vu HA, Xinh PT, Kano Y, Tokunaga $K$, Sato Y: The juxtamembrane domain in ETV6/FLT3 is critical for PIM-1 up-regulation and cell proliferation. Biochem Biophys Res Commun 2009, 383:308-313.
99. Gomez-Abad C, Pisonero H, Blanco-Aparicio C, Roncador G, González-Menchén A Martinez-Climent JA, Mata E, Rodríguez ME, Muñoz-González G, Sánchez-Beato M, Leal JF, Bischoff JR, Piris MA: PIM2 inhibition as a rational therapeutic approach in B-cell lymphoma. Blood 2011, 118:5517-5527.

100. Brault L, Menter T, Obermann EC, Knapp S, Thommen S, Schwaller J, Tzankov A: PIM kinases are progression markers and emerging therapeutic targets in diffuse large B-cell lymphoma. Br J Cancer 2012, 107:491-500.

101. Hsi ED, Jung SH, Lai R, Johnson JL, Cook JR, Jones D, Devos S, Cheson BD, Damon LE, Said J: Ki67 and PIM1 expression predict outcome in mantle cell lymphoma treated with high dose therapy, stem cell transplantation and rituximab: a Cancer and Leukemia Group B 59909 correlative science study. Leuk Lymphoma 2008, 49:2081-2090.

102. Pasqualucci L, Neumeister P, Goossens T, Nanjangud G, Chaganti RS, Küppers R, Dalla-Favera R: Hypermutation of multiple proto-oncogenes in B-cell diffuse large-cell lymphomas. Nature 2001, 412:341-346.

103. Claudio JO, Masih-Khan E, Tang H, Gonçalves J, Voralia M, Li ZH, Nadeem V, Cukerman E, Francisco-Pabalan O, Liew CC, Woodgett JR, Stewart AK: A molecular compendium of genes expressed in multiple myeloma. Blood 2002, 100:2175-2186.

104. Pogacic V, Bullock AN, Fedorov O, Filippakopoulos P, Gasser C, Biondi A, Meyer-Monard S, Knapp S, Schwaller J: Structural analysis identifies imidazo[1,2-b]pyridazines as PIM kinase inhibitors with in vitro antileukemic activity. Cancer Res 2007, 67:6916-6924.

105. Blanco-Aparicio C, Collazo AM, Oyarzabal J, Leal JF, Albarán MI, Lima FR, Pequeño B, Ajenjo N, Becerra M, Alfonso P, Reymundo MI, Palacios I, Mateos G, Quiñones H, Corrionero A, Carnero A, Pevarello P, Lopez AR, Fominaya J, Pastor J, Bischoff JR: Pim 1 kinase inhibitor ETP-45299 suppresses cellular proliferation and synergizes with PI3K inhibition. Cancer Lett 2011, 300:145-153.

106. Garcia PD, Langowski JL, Wang $Y$, Chen M, Castillo J, Fanton C, Ison M, Zavorotinskaya T, Dai Y, Lu J, Niu XH, Basham S, Chan J, Yu J, Doyle M, Feucht P, Warne R, Narberes J, Tsang T, Fritsch C, Kauffmann A, Pfister E, Drueckes P, Trappe J, Wilson C, Han W, Lan J, Nishiguchi G, Lindvall M, Bellamacina C, Aycinena JA, Zang R, Holash J, Burger MT: Pan-PIM kinase inhibition provides a novel therapy for treating hematologic cancers. Clin Cancer Res 2014, 20:1834-1845.

107. Chen LS, Redkar S, Bearss D, Wierda WG, Gandhi V: Pim kinase inhibitor, SGI-1776, induces apoptosis in chronic lymphocytic leukemia cells. Blood 2009, 114:4150-4157.

108. Chen LS, Redkar S, Taverna P, Cortes JE, Gandhi V: Mechanisms of cytotoxicity to Pim kinase inhibitor, SGI-1776, in acute myeloid leukemia. Blood 2011 118:693-702.

109. Yang Q, Chen LS, Neelapu SS, Miranda RN, Medeiros LJ, Gandhi V: Transcription and translation are primary targets of Pim kinase inhibitor SGI-1776 in mantle cell lymphoma. Blood 2012, 120:3491-3500.

110. Hospital MA, Green AS, Lacombe C, Mayeux P, Bouscary D, Tamburini J: The FLT3 and Pim kinases inhibitor SGI-1776 preferentially target FLT3-ITD AML cells. Blood 2012, 119:1791-1792.

111. Fischer KM, Cottage CT, Konstandin MH, Völkers M, Khan M, Sussman MA: Pim-1 kinase inhibits pathological injury by promoting cardioprotective signaling. J Mol Cell Cardiol 2011, 51:554-558.

112. Quijada P, Toko H, Fischer KM, Bailey B, Reilly P, Hunt KD, Gude NA, Avitabile D, Sussman MA: Preservation of myocardial structure is enhanced by pim-1 engineering of bone marrow cells. Circ Res 2012, 111:77-86.

113. Lin YW, Beharry ZM, Hill EG, Song JH, Wang W, Xia Z, Zhang Z, Aplan PD, Aster JC, Smith CD, Kraft AS: A small molecule inhibitor of Pim protein kinases blocks the growth of precursor T-cell lymphoblastic leukemia/ lymphoma. Blood 2010, 115:824-833.

114. Beharry Z, Zemskova M, Mahajan S, Zhang F, Ma J, Xia Z, Lilly M, Smith CD Kraft AS: Novel benzylidene-thiazolidine-2,4-diones inhibit Pim protein kinase activity and induce cell cycle arrest in leukemia and prostate cancer cells. Mol Cancer Ther 2009, 8:1473-1483.

115. Dakin LA, Block MH, Chen H, Code E, Dowling JE, Feng X, Ferguson AD, Green I, Hird AW, Howard T, Keeton EK, Lamb ML, Lyne PD, Pollard H, Read J, Wu AJ, Zhang T, Zheng X: Discovery of novel benzylidene-1, 3-thiazolidine-2,4-diones as potent and selective inhibitors of the PIM-1, PIM-2, and PIM-3 protein kinases. Bioorg Med Chem Lett 2012, 22:4599-4604.

116. Meja K, Stengel C, Sellar R, Huszar D, Davies BR, Gale RE, Linch DC, Khwaja A: PIM and AKT kinase inhibitors show synergistic cytotoxicity in acute 
myeloid leukaemia that is associated with convergence on mTOR and MCL1 pathways. Br I Haematol 2014, 167:69-79.

117. Brzózka K, Windak R, Guratowska M, Krawczyńska K, Kłosowska-Wardęga A, Zurawska M, Trębacz E, Sabiniarz A, Czardybon W, Chołody M, Horvath R, Szamborska-Gbur A, Prymula K, Milik M, Kowalczyk P, Rzymski T, Beuzen N: Preclinical development of a Pim kinase inhibitor for cancer treatment. [abstract]. Cancer Res 2012, 72:s1.

118. Keeton EK, McEachern K, Dillman KS, Palakurthi S, Cao Y, Grondine MR, Kaur S, Wang S, Chen Y, Wu A, Shen M, Gibbons FD, Lamb ML, Zheng X, Stone RM, Deangelo DJ, Platanias LC, Dakin LA, Chen H, Lyne PD, Huszar D: AZD1208, a potent and selective pan-Pim kinase inhibitor, demonstrates efficacy in preclinical models of acute myeloid leukemia. Blood 2014, 123:905-913.

119. Fathi AT, Arowojolu O, Swinnen I, Sato T, Rajkhowa T, Small D, Marmsater F, Robinson JE, Gross SD, Martinson M, Allen S, Kallan NC, Levis M: A potential therapeutic target for FLT3-ITD AML: PIM1 kinase. Leuk Res 2012, 36:224-231.

doi:10.1186/s13045-014-0095-z

Cite this article as: Mondello et al:: Pim kinases in hematological malignancies: where are we now and where are we going? Journal of Hematology \& Oncology 2014 7:95.

\section{Submit your next manuscript to BioMed Central and take full advantage of:}

- Convenient online submission

- Thorough peer review

- No space constraints or color figure charges

- Immediate publication on acceptance

- Inclusion in PubMed, CAS, Scopus and Google Scholar

- Research which is freely available for redistribution 